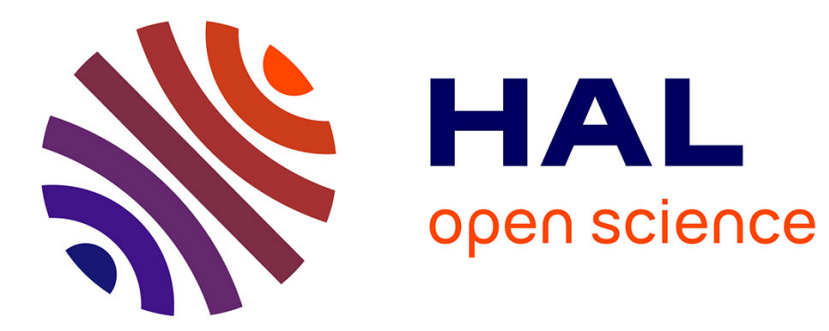

\title{
Economic thought in scholasticism
}

Irina Chaplygina, André Lapidus

\section{To cite this version:}

Irina Chaplygina, André Lapidus. Economic thought in scholasticism. G. Faccarello et H. Kurz (eds), Handbook on the History of Economic Analysis, Cheltenham (UK) / Northampton (USA): Edward Elgar, vol. 2, pp. 20-42., 2016, 10.4337/9781785367366.00008 . hal-01619017

\section{HAL Id: hal-01619017 \\ https://hal-paris1.archives-ouvertes.fr/hal-01619017}

Submitted on 18 Oct 2017

HAL is a multi-disciplinary open access archive for the deposit and dissemination of scientific research documents, whether they are published or not. The documents may come from teaching and research institutions in France or abroad, or from public or private research centers.
L'archive ouverte pluridisciplinaire HAL, est destinée au dépôt et à la diffusion de documents scientifiques de niveau recherche, publiés ou non, émanant des établissements d'enseignement et de recherche français ou étrangers, des laboratoires publics ou privés. 


\section{Economic Thought in Scholasticism}

\section{Irina Chaplygina $^{*}$ and André Lapidus** \\ in G. Faccarello et H. Kurz (eds), \\ Handbook on the History of Economic Analysis,}

Cheltenham (UK) / Northampton (USA): Routledge, 2016, vol. 2, pp. 20-42.

Medieval economic views can be reconstructed only indirectly, through the works of theologians, moralists, lawyers, and philosophers for whom such issues did not constitute a field that deserved to be considered separately. Even texts that are directly related to specific economic problems, such as money lending, only make sense as part of a more general perspective. In general, economic views are restricted to certain paragraphs in the Summa, the commentaries on Aristotle's works on ethics or politics, or comments on contracts in canon or civil law. These economic ideas therefore appear as a kind of projection from theological, philosophical, moral, political or legal concepts to the economic aspects of social life, especially as they concern human behaviour.

In this respect, the economic reasoning of the Middle Ages could not be considered an economic theory in the modern sense. Characterized by a comparative approach, it consists of two procedures. First, within the framework of general conceptions of society, a norm for economic activity is formed. Secondly, economic behaviour and, further, economic intentions, are analysed and assessed for whether they conform to that norm. Understanding this duality is particularly important since it permits an explanation of certain apparent contradictions between the various judgements of the schoolmen. Moreover, it helps prevent the erroneous though widespread tendency to read medieval economic analysis through exclusively normative glasses: whatever the norm is (a just price, for instance), the existence of a possible gap between this norm and actual transactions requires an explanation to support the judgement of the moralist, whether priest or judge. The elements of medieval economic analysis lie in this explanation.

\footnotetext{
* State University of Moscow, Russia

** Phare, University Paris 1 Panthéon-Sorbonne, France
} 
This does not mean that apparently familiar economic categories (price, interest, exchange, money, and competition) can be understood as they would be today. What makes them unfamiliar is their dependence both on specific conceptions of society, and on the specific goals of the age.

Three main sources formed the intellectual basis of the economic thought of the Middle Ages. The first comprises the traditional teaching of the church, drawing on the Gospels and on the wide corpus of patristic literature. The second source is provided by the Latin translations of Aristotle, mainly his Nicomachean Ethics and his Politics, which spread across the western world during the thirteenth century. Usually these translations were indirect, since Aristotle's moral and philosophical works were known from previous translations by Muslim and Jewish commentators. The third source is Roman law, rediscovered through the works of glossators during the second half of the eleventh century. These three sources sustained an ambitious project, initiated by Albert the Great and his follower Thomas Aquinas, as a reaction against the spread of the doctrine of the double truth - truth of reason and truth of faith - attributed to Averroes, and taught in Paris by Siger of Brabant. The purpose of this project was the conciliation of reason and faith by showing that faith is founded on reason. Aristotle's philosophy here played a crucial role, in that it allowed the rationalization of theological doctrines.

On first sight, this seems far from economic matters. Nonetheless, philosophical positions such as Albert's and Thomas's brought with them a conception of society which is worth mentioning from the viewpoint of such matters. From Aristotle they borrowed a teleological and organicist conception of society. The first feature gives rise to a hierarchy of natures, which goes from inanimate things up to vegetables, animals, men, and, at the top of the pyramid, God. Since the end of each level in this hierarchy is to be found in the higher level, men appear on this earth not only as God's creatures, but as agents of the Creation, endowed with reason. The second feature draws on Aristotle's political philosophy, for instance on Politics, book 1, where he argued that man is a "political animal", since his ends and capacities can be satisfied only through his function within the political organization of the City, just like any particular organ within the organism of which it is a part. This does not only mean that, as Thomas argued, again following "the Philosopher" (Aristotle), "the whole must of necessity be prior to the part" (Thomas Aquinas, Summa Theologiae, IIa-IIae, q.58, a.5, resp.), but that our place in society as a part of it conforms to an external hierarchy of ends which, as beings endowed with reason, it is our task to discover. 
However, society was far from being considered only from the point of view of Thomism. In 1277 - that is, three years after Thomas Aquinas's death - Averroist theses were condemned by the Bishop of Paris. It was clear to everyone that, behind Averroës, this condemnation was aimed at the teachings of Aquinas, whose eminent position was not all that firmly established outside the Dominican order. As early as the beginning of the fourteenth century, there was a gradually increasing influence of alternative trends of thought coming mainly from the Franciscan order, through figures such as John Duns Scotus and William of Ockham who set out what is now known respectively as "Scotism" and "nominalism". From a philosophical point of view, both might be seen as ways of importing other influences (Plato and, concerning Islamic philosophy, Avicenna), of reframing the influence of Aristotle, or even of moving away from it. However, it was also a way to provide more individualistic foundations to the conception of society, either through a contractualist approach (Scotism), or through an approach which dismissed the possibility that a category like "men" in general, independently from the particularities of each single individual, might constitute the basis of society (nominalism).

These considerations are far from strictly academic, since they explain some of the variants of the analysis of economic categories among the schoolmen.

\section{Price and Just Price}

Just price is the most typical example of an economic category which has different interpretations in medieval literature. Baldwin (1959:8) found the first occurrence of the phrase in Babylon, at the time of the fourth successor of Hammurabi. However, the medieval theologians and jurists encountered it via Roman law, in the Corpus Juris Civilis, notably in passages related to contracts such as those concerning the problem of the laesio enormis. Further, the just price occurs in the theological literature of the end of the twelfth century, as in Peter Cantor, or at the beginning of the thirteenth century, as in Robert of Courçon or Alexander Hales.

Nevertheless, although the rough intuition of a price which might be considered as just from a moral or legal viewpoint does have an ancient origin, the first systematic presentation of the concept, accessible to contemporary economists, appears no earlier than in the writings of Albert the Great and his pupil Thomas Aquinas. As such, it expresses the basic requirements of any moralist broadly speaking (for instance, a priest or a judge): knowing 
whether such-and-such a price for such-and-such a transaction is morally acceptable or not, requires (1) that a norm of acceptability is made explicit - the just price, and (2) that any difference from this norm is explained in moral terms. This basic requirement was evidently not restricted to Thomism, since it was shared by its opponents, and still appears as a major theme in the sixteenth century - within the revival of Thomism which since Marjorie GriceHutchinson's works has been known as the "School of Salamanca" (Grice Hutchinson 1952, 1978; Tortajada 1992); in the works of the founders of natural law philosophy during the seventeenth century such as Hugo Grotius and Samuel von Pufendorf; and even in the eighteenth century, in Turgot's works. However, during this long process of evolution, its initial content vanished.

This should be taken seriously: not only had the meaning of the "just price" been transformed since its analytical origin in the thirteenth century, but it is too dependent on concerns different from ours to be easily approached through our current economic categories. However, there remains a persistent tendency to view the just price - that is, the norm of morality within a transaction - as something of a trailblazer for market price theory (see, for instance, De Roover 1958, 1971; Baldwin 1959; Barath 1960).

Intuitively, this point of view is far from unreasonable: the persistent struggle of schoolmen against corporations of merchants, trade associations and many other kinds of collusion, or the development of fairs all over Europe, suggest that the intuition of a market mechanism already existed. In the same way, reference in the works of several schoolmen, including Thomas Aquinas, to such notions as "demand" or "utility", contributes to this impression.

However, a more nuanced investigation shows that such an interpretation makes poor sense. For instance, the schoolmen's opposition to various kinds of monopoly does not lead to an understanding, similar to ours, of the competitive mechanism which leads to market price. Rather, it is linked to moral judgements, which condemn such contracts where justice is violated because of the asymmetric position of the parties. The existence of fairs, which we rightly consider today as "markets", only means that markets as institutions already existed: not that for all those who were involved in that institution, the market was also a theory. Moreover, even though Latin expressions such as indigentia or utilitas were often translated respectively as "demand" or "utility", this does not imply that both of them had the subjective meaning to which we are today accustomed: indigentia denotes a social need, and utilitas refers to an admitted social use which has nothing to do with individual fancy. 


\section{Thomas Aquinas on the analysis of price}

Thomas Aquinas's writings on price are not numerous. To his commentaries on Aristotle's Ethics and Politics should be added the questions on justice from the Summa Theologica (II ${ }^{\mathrm{a}}$ $\mathrm{II}^{\mathrm{ae}}$, especially question 77), as well as passages from more specific works, such as that on forward transactions, De Emptione et Venditione ad Tempus. These passages elaborate on the comments on Aristotle provided by Thomas Aquinas's master, Albert the Great, showing once again the influence of the philosopher, which brings with it both the Church Fathers' traditional teaching and the legacy of Roman law. The representation of price therefore appears as an outcome of a more general understanding of social interactions, within which the question of ownership plays a crucial part.

\section{Private property and natural law}

Although scholastic views on property had moved away from those of the Church Fathers, such as Ambrose or John Chrysostom, who argued in favour of collective property, private property never obtained the status of a full natural right. Thomas Aquinas's views typify this persistent gap between private property (to which he devoted the whole article 2 of question 66 from IIa-IIae of the Summa) and natural law. He justified the principle of ownership (whatever its type) of external things as a consequence of the place of men in the plan of the Creation (Summa Theologica, $\mathrm{II}^{\mathrm{a}}-\mathrm{II}^{\mathrm{ae}}$, q.66, a.1, ad 1): as reasonable beings, men are not only created by God, they are also agents of the Creation, contributing to its accomplishment. The "power to manage and to distribute" (potestas procurandi et dispensandi) should therefore be understood not as the expression of an exclusive and transferable property right, but as a faculty required in order to fulfil the divine plan. Such a position legitimates human property as a way to reach the goals of human community as a whole, according to its place in the hierarchy of natures.

As a result, the introduction of private property should not be understood as a way to take into account a hitherto neglected individual and subjective dimension: it is only a way to reach the common goal more efficiently: Thomas reminds us of the greater "care" (cura) that we give to what we possess privately (Summa Theologica, II $^{\mathrm{a}}-\mathrm{II}^{\mathrm{ae}}$, q.66, a.2, resp). Thus, the individual dimension appears only as a moral and religious one, through the responsibility of each human being to share or to reject this common goal. Similarly, although private property evidently has something to do with natural law, this is not immediate, as an 
unquestionable part of it, but only indirect. As for Augustine, and according to a distinction already present in Roman law, private property rights are considered something added by human reason as a more convenient way of contributing to the common good, pertaining to what will be known as the "human right" - jus gentium.

\section{The theory of the just price}

Thomas's conception of the just price is the core of question 77 from the Summa Theologica $\left(\mathrm{II}^{\mathrm{a}}-\mathrm{II}^{\mathrm{ae}}\right)$. As such, it is a part of a reflection on the injustice committed in a context of voluntary exchange. This emphasis on justice or injustice in exchange shows that the just price is assumed to be "just" according to what Aristotle named "particular justice", which could be either commutative or distributive. (Summa Theologica, II $^{\mathrm{a}}-\mathrm{II}^{\mathrm{ae}}$, q.61, a.3, resp. Rigorously speaking, Aristotle distinguished three (and not two) kinds of particular justice: distributive, reciprocal, and corrective. The confusion between the two last kinds of justice in the category of "commutative" justice seems to have been an effect of the Latin translations which were used throughout the Middle Ages, particularly in the works of Albert and Thomas; see, for instance, Summa Theologica, $\mathrm{II}^{\mathrm{a}}-\mathrm{II}^{\mathrm{ae}}$, q.61, a.1, sed contra.)

In commutative justice, whose primary concern is "selling and buying", Thomas Aquinas said that "it is necessary to equalize thing with thing", whereas distributive justice deals with the distribution of "common goods" among individuals "according to proportion between things and persons", that is, according to the respective "position[s] in the community" in that it reflects individual contributions to the realization of the goals of the society (Summa Theologica, $\mathrm{II}^{\mathrm{a}}-\mathrm{II}^{\mathrm{ae}}$, q.61, a.2, resp). Again following Aristotle, he argued that commutative and distributive justice can be distinguished in that the first specie of justice achieves an arithmetic proportion, and the second one a geometric proportion (Summa Theologica, $\mathrm{II}^{\mathrm{a}}-$ $\mathrm{II}^{\mathrm{ae}}$, q.61, a.2, ad 2).

The part played by commutative justice is obvious, since it explicitly deals with commutatio, that is, with exchange. The equality of thing to thing which characterizes it draws its importance from what it excludes: in one way, this equality depends on conditions of place, time and risk; but in another way, it depends neither on the social hierarchy between the persons involved in the transaction, nor on any natural hierarchy between the things exchanged. This gives a determining part to what Thomas called indigentia, often translated as "need" or "utility", and explains why, in contrast with the hierarchy of natures and according to a well-known example from Augustine (Of the City of God, XI), a horse might 
be more expensive than a slave (see Aquinas's Summa Theologica, $\mathrm{II}^{\mathrm{a}}-\mathrm{II}^{\mathrm{ae}}$, q.77, a.2, ad 3 and Ethicorum ad Nichomachum - hereafter Ethicorum - V, 9).

Among some commentators (see, for instance, De Roover 1971: 49-50), such reference to "need" constituted an argument in support of the idea that the scholastic theory of the just price constituted the first stone of a theory of price based on subjective utility. However, although it is obvious that exchange was viewed as a mutual advantage (Ethicorum, V, 9; Summa Theologica, $\mathrm{II}^{\mathrm{a}}-\mathrm{II}^{\mathrm{ae}}$, q. 77 , a.1, resp.), it is difficult to allow that phrases such as indigentia anticipate the subjective content of individual preferences in the modern sense (see Lapidus 1986: 20-21, 1992: 34, and the lexical discussion in Langholm 1987: 122-5). On the contrary, indigentia seems to refer to a socially acknowledged norm which associates things and human needs in the same way as a tool is associated to its use. Such universality shows that these needs accord not with individual fancy, but with the requirements of society as a whole - with public felicity.

This is why commutative justice is tightly connected with distributive justice. Now, distributive justice primarily deals with the distribution, among individuals, of a common good, ruled by their respective positions within the society. As Thomas Aquinas explains, "in distributive justice a person receives all the more of the common goods, according as he holds a more prominent position in the community" (Summa Theologica, $\mathrm{II}^{\mathrm{a}}-\mathrm{II}^{\mathrm{ae}}$, q. 61, a. 2, resp.). The "common good" dimension of distributive justice should not mislead us. In the same question of the Summa, after having explained the differences between commutative and distributive justice, Thomas Aquinas stresses their similarity, using a most interesting analytical argument which states that externalities might be internalised in the same way as internalities might be externalised: "things can be taken out of the community in order to be distributed among individuals as much as exchanged between them" (Summa Theologica, $\mathrm{II}^{\mathrm{a}}-\mathrm{II}^{\mathrm{ae}}$, q. 61 , a. 3, resp.). This should be taken seriously. It means that selling private goods can be viewed as an equivalent to distributing a public good, through the income distribution to which it gives rise - what was to be called the "labour and expenses" of the merchants. It is obvious that this might give birth to two kinds of retrospective biases.

The first retrospective bias comes from the way we interpret the social hierarchy which is reflected by the hierarchy of incomes generated by the price of a good. Since this social hierarchy constitutes an expression of the relative merits of the members of a society, it seems rather easy to consider such merit as an expression of individual contributions, which would foreshadow marginal productivity (for a criticism of the marginal productivity 
interpretation of the incomes generated by distributive justice, see Wilson 1975: $63 \mathrm{ff}$.). Nonetheless, it should be stressed that although individual merit matters, it is not according to the production of material wealth, but to its contribution to a common end which gives rise to public felicity - in contrast to private well-being.

This should be kept in mind in order to avoid the second retrospective bias, which would lead us to question the consistency of the just price with both needs (according to commutative justice) and income distribution (according to distributive justice). When taken into account, such possible inconsistency has led commentators to support the idea of a coexistence of two alternative theories of the just price in Thomas's works (see Hollander 1965), or of a quasi-Smithian gravitation theory involving two prices (De Roover 1958: 421 ff.), or, finally, of a kind of prefiguration of the distinction between short-term and long-term market price (Barath 1960). However, the prerequisite for such interpretations - that is, the mere possibility that a price might be just in two different ways, generating two different magnitudes - would be meaningless at least within Albert's and Thomas's legacy, where a teleological and organicist conception of society results in the consistency between common end and social hierarchy (see Lapidus 1986, 1992).

\section{Price and moral behaviour: the determination of actual prices}

The just price constitutes a norm of acceptability of price, which is rooted in a moral point of view of what is "just". As such, it is a part of a broader device which takes into account the exchangers' morality in order to explain why such an actual price would depart from or, to the contrary, match the norm of the just price. Three types of situation give rise to a possible deviation from the just price: (1) lack of information; (2) manipulation of information; and (3) exchange by accident.

In the two first types of situation, the part played by the morality of the seller and of the buyer is linked to the role of information not about the just price itself (which is assumed to be known, or easily knowable, by everyone), but about the goods and on the conditions of the transaction. The examples which Thomas Aquinas introduced in question 77 of the secunda secundae all suggest the same kind of process (see Lapidus 1994): whereas in (1) a lack of information might make the actual price depart from the just price to the detriment of any of the parties without any sinful intention, the same lack of information by one party in (2) can also be manipulated purposefully to his detriment by the other party, so that the gap between the actual price and the just price now constitutes the fraud denounced in question 77 . On the 
contrary, a potential transaction between a virtuous seller and a virtuous buyer, both accurately informed about the good and the transaction, represents a kind of reference to which the actual transaction is compared. In such virtuous and informed situations, the behaviour of each agent is described as a consequence of a switch between each one's point of view, drawing on Matthew 7.12: "All things whatsoever ye would that men should do to you, do ye even so to them" (Summa Theologica, II ${ }^{\mathrm{a}}-\mathrm{II}^{\mathrm{ae}}$, q. 77, a. 1, sed contra). When the buyer and the seller are both informed about the just price, this means that the first aims at paying at least the just price and that the second aims at paying at most the just price, so that this last becomes the only actual price acceptable by the two sides of the transaction. In the last type of situation, (3), exchange is viewed as an accidental operation (exchange per accidens, which relates to the Aristotelian theory of categories; see Summa Theologica, II ${ }^{\mathrm{a}}-$ $\mathrm{II}^{\mathrm{ae}}$, q. 77 , a. 1, resp.) between a particular buyer and seller who are familiar to each other and, as a result, sufficiently aware of the conditions under which such an object is sold or bought to be morally involved in the transaction, so allowing the actual price to depart from the just price on the basis of these specific conditions. Thomas Aquinas argued:

[I]f the one man derive a great advantage by becoming possessed of the other man's property and the seller be not at a loss through being without that thing, the latter ought not to raise the price, because the advantage accruing to the buyer, is not due to the seller, but to a circumstance affecting the buyer. (Summa Theologica, II $^{\mathrm{a}}-\mathrm{II}^{\mathrm{ae}}$, q. 77, a. 1, resp.)

Such a representation of the way a transaction is concluded did not lead to any condemnation of the trade which gives birth to profit in itself, and Thomas's position might be viewed as a continuation of Augustine's, which he quotes as follows: "The greedy tradesman blasphemes over his losses; he lies and perjures himself over the price of his wares. But these are vices of the man, not of the craft, which can be exercised without these vices." The conclusion is straightforward: "Therefore trading is not in itself unlawful" (Summa Theologica, II'-II ${ }^{\mathrm{ae}}$, q. 77, a. 4, sed contra). Consequently, the regulation process which aims at excluding vicious behaviour does not concern profitable trade in itself, but the existence of opportunities of fraud. Both information-providing and information-seeking are clearly encouraged: such is the case of the virtuous buyer of a book, who is expected to inform his seller of its high value (Summa Theologica, $\mathrm{II}^{\mathrm{a}}-\mathrm{II}^{\mathrm{ae}}$, q. 77, a. 1, ad 2); or of the brass that the seller mistakes for gold (Summa Theologica, $\mathrm{II}^{\mathrm{a}}-\mathrm{II}^{\mathrm{ae}}$, q. 77, a. 2, resp.). But Thomas's solution can be more indirect, in particular when vicious behaviour not only arises from the possibility to manipulate the information, but also from the dominating position of one of the parties in the negotiation. In such a situation, a virtuous seller is allowed to protect himself from the potential vicious 
behaviour of a powerful buyer by keeping for himself some easily available information. A significant example is given in Summa Theologica, II $^{\mathrm{a}}$-II ${ }^{\mathrm{ae}}$, q. 77, a. 3, resp., with the case of the "one-eyed horse". Thomas Aquinas comes to such a conclusion at the end of a comparative analysis of hidden and evident vices that may affect a commodity:

\footnotetext{
But when the defect is evident, as for a one-eyed horse; ... if, as a result of this defect, he [the seller] decides on his own to lower the price, he is not bound to reveal the defect of the thing. For it is possible that as a result of this defect a buyer might want to reduce the price to lower than it should be. In this case, the seller can licitly wish to protect himself against any loss by not disclosing the fact that the thing is defective. (Summa Theologica, $\mathrm{II}^{\mathrm{a}}-\mathrm{II}^{\text {ae }}$, q. 77 , a. 3, resp.)
}

\section{Price and individual behaviour: alternatives to Thomistic issues}

In spite of its importance, Thomas Aquinas's teaching did not remain unchallenged. From the beginning of the fourteenth century, such challenges seem to have jeopardized the elegant construction he had achieved, giving more room to individual behaviour. This was clearly linked to the growing distance between the analysis of price and the organicist understanding of society, which followed Thomas Aquinas's death in 1274. An outstanding symptom of this period of intellectual upheaval was the condemnation of the so-called "Averroist theses" by the Bishop of the University of Paris in 1277: Thomas Aquinas's influence within these theses was clear to everyone concerned. From a philosophical, religious, and political point of view, this period is now well known (see Gilson 1944 [1955]: chs 8 and 9). The ensuring development of alternatives to Aristotle's authority, at least in its Thomistic version, made possible the birth of individualistic approaches, mainly among the Franciscan order, with John Duns Scotus or the nominalist authors, for instance. Now, however, the puzzling observation can be made that the resulting theory of price was not so remote from its Thomistic predecessor.

It seems clear today that most authors fell into the same logical trap, generated by the lack of a demand function relating a list of prices and a list of quantities, which results from the demands formulated by all those who are interested in the good. Such a representation would be consistent with the idea that people usually have different needs, since this difference does not lead to a difference in prices, but to a difference in the quantities demanded. Within the nominalist tradition, this is evident, for instance, from John Buridan's comments on Aristotle's claim in the Ethics that need is a measure of price. If individual (and, therefore, different) needs do constitute a measure of price, "the poor should buy corn at higher price 
than the rich, since he needs corn more than the rich" (Buridan 1637, V, q.16, doubt 1). The famous Rector of the University of Paris at the beginning of the fourteenth century tried to bypass his own objection by arguing that each one gives what he has in excess - money for the rich, and labour for the poor. Nonetheless, this might explain how the poor should get money to buy grain, but not why both the poor and the rich should pay the same amount for the same quantity of corn. The same could be said, for instance, about Henry of Langenstein (Henry of Hesse), at the end of the fourteenth century. In his Tractatus de Contractibus, he is also faced with the idea that if individual needs are related to prices, this would mean that no one would pay the same price, and that the poor would be charged more than the rich.

The difficulty was the same and, to some extent, Buridan's and Langenstein's solutions were convergent. Whereas Buridan argued that the kind of need which measures the price of corn is the "common need" (indigentia communis) of those who are able to perform such exchanges, Langenstein also favoured the "common need", now understood as the part of individual need which is similar for each of us, since it rests on moral grounds and not on fancy or passions (voluptas or cupiditas). The resulting device was quite close to the main features of Thomas's theory of price, in spite of the attempt to give it a more individualistic foundation (on Buridan and Langenstein's analysis and, for other examples, see Lapidus 1992: 37-42). A referential norm is introduced as a just price: this fulfils the requirements of commutative and distributive justice as in Thomas Aquinas, and departures from this norm might be explained from a moral or informational point of view.

Interestingly, such a logical trap - making it difficult to conceive a unique price as a result from unequal individual needs - constituted an obstacle to the development of what is known as a subjective theory of value, at least until the concept of a demand function was unambiguously accepted among the predecessors of the marginalist revolution.

\section{Interest and Usury}

The great period of the medieval theory of interest and of the associated doctrine of usury might be viewed as a long thirteenth century, beginning in the mid-twelfth century with the Decretum by Gratian and ending in the first years of the fourteenth century with the Tractatus de Usuris by Alexander Lombard. Historically, it might be viewed as one aspect of a broader history concerning the three great monotheisms (see Ege 2014). Analytically, as in 
the case of the conception of price, the problem of interest rests on an entanglement of its positive and its normative side: properly speaking, the theory of interest and the doctrine of usury. For a modern reader, this entails the methodological prerequisite of dis-entanglement, although the neglect of such prerequisite also has a relevant history - namely, the history of economists who have sought precursors of their theories in the thought of the Middle Ages. We find, for instance, a most suggestive prefiguration of the idea that only business profit raises interest above zero (Schumpeter 1954: 105) or that underemployment could be efficiently fought by increasing the incentive to invest, which means lowering interest rates (the argument, found in Sommerville 1931, is taken up by Keynes 1936 [1973]: 351-2).

Hereafter, we will try not only to separate positive and normative statements, but also to explain how and why they were embedded. On the one hand, we can consider as granted that the schoolmen did have explanations of a possible difference between the amount lent on the occasion of a money loan and the amount paid back by the borrower. On the other hand, all explanations were not equally acceptable on moral grounds. From this point of view, this seems similar to what we have already encountered in the case of the analysis of price: a play with three characters - the two participants in the transaction (here, a creditor and a debtor) and the moralist (for instance, a priest, or a judge at an ecclesiastical court).

During this period, the explanations given for the difference between the money lent and the money paid back looked very much like those we are familiar with today: they favoured, not exclusively, time preference, technical productivity, risk-taking, liquidity preference, and negotiation power. Nonetheless, from a moral point of view, at least one of them was clearly not admissible: the use of greater power in negotiation in order to obtain this difference, which today we would naturally view as interest. However, the mere factual existence of interest does not by itself show how it should be explained. The creditor and the debtor might know it, but the moralist does not.

Such a perspective, which views the problem faced by the moralist as a variant of a classical asymmetric information problem, constitutes an efficient reading guide for controversies which ran throughout the long thirteenth century, and helps dispel the impression of confused, if not indeed contradictory, statements. The various positions of the schoolmen regarding usury can be understood as so many attempts to avoid the committing of a major sin, and to obtain the relevant information on the actual interpretation of interest which should prevail. 
These discussions on interest and usury dealt with money, either directly in the case of money-lending, or indirectly in the case of other operations regarded as possible substitutes for money-lending. In these discussions, the focus was on the morality of the lender and of the borrower, on their respective negotiation power, and on their information, with the question of the value of the money lent remaining in the background.

\section{The value of money: conventionalist versus metalist view}

At first sight, the medieval conception of money, typically seen as running from Thomas Aquinas to John Buridan and Nicholas Oresme (at the beginning and in the middle of the fourteenth century), draws on the same sources: Aristotle's Politics book I and, to a lesser degree, Ethics book V (see Langholm 1983). However, this common Aristotelian legacy had been interpreted and developed in two different ways: a conventionalist conception of money for Thomas Aquinas (the valor impositus), and a metalist conception for John Buridan and Nicholas Oresme (see Lapidus 1997; this distinction can be traced back in the secondary literature to Bridrey 1906 and to Gordon 1961).

At first sight, the conceptions share a similar starting point. Thomas Aquinas considered that the rise of money was "ordered by nature" out of a barter situation, as a means of exchange and of measure (Politicorum, I, 7). Something similar can be read in Buridan's comments on book $\mathrm{V}$ of the Ethics, when he impressively argued that money is an appropriate solution to the scattering of sellers and buyers, to the non-simultaneity of needs, to the gap between possessions and needs, and to the indivisibility of goods (Ethicorum, V, q. 17, a. 1, proofs 1, 2, 3, and 4). Though based on a reflection on the destiny of Adam's posterity after the Fall, the same analysis could be found in the first chapter of Oresme's influential book on monetary matters, Treatise on Money.

However, on closer examination it becomes clear that the paths followed by Thomas Aquinas on the one hand, and by Buridan and Oresme on the other, depart from one another.

According to Thomas Aquinas, money, as the highest form of exchange, though ordered by nature, is separated from it: "[I]t is convenient that there be a single thing which could measure everything, and this thing does not measure according to its nature, but because men decided for it to be" (Ethicorum, V, 9). 
As a measure, Thomas Aquinas explained, money does not depend on the nature of things but on the will of men. This gives rise to the recurrent etymological observation that "specie is called numisma, which comes from nomos, the law, because specie is not measured by nature, but by law. It is our power to transform it or to make it useless" (Ethicorum, V, 9). Or, in the words of the commentaries on the Politics, it "will be of price nil if the King or the community decides that it is worthless" (Politicorum, I, 7).

On the contrary, for Buridan as for Oresme, the link between the natural origin of money, the metal it is made of, and its value, cannot be broken. For instance, when commenting on the Ethics, Buridan clearly aimed at challenging the Thomistic interpretation of Aristotle's conception of money as valor impositus: "Some people [like Thomas Aquinas; I.C. and A.L.] say that the prince imposes the quantity of value of the money, and that, according to the imposed value, it measures the exchanges: this is why Aristotle said that money is not by nature, but by name, and it is up to us to make it useless" (Ethicorum, V, q. 17, a. 2). However, Buridan continued, this only means that whereas the prince can impose the name of the money (call it, for instance, "denier" or "obole"), he may not commit the injustice of imposing its value. This is because the property of money to be a measure of value depends on its being constituted by a material which is, itself, the object of human needs and, therefore, measured by them. In Buridan's words, this amounts to saying that money is not an immediate but an intermediary measure of values (Ethicorum, V, q. 17, a. 2). Buridan echoes Thomas Aquinas's idea of a double measure, natural (need) and artificial (money). See also Oresme, (Traduction et Glose de l'Ethique d'Aristote, V, ch. 11) who used a Thomistic vocabulary for a Buridan-like purpose). As a measure of value, money therefore remains anchored in the metal from which it is made.

Oresme's writings especially took into account the effects of the link between money and metal. Again reading the Politics, he transposed to money the Aristotelian difference between the "principal use" and the "secondary use" of a good, namely consumption and exchange (Traduction et Glose de la Politique d'Aristote, I, 10), claiming that the specificity of money is an inversion of content between its principal and its secondary use. As a result, the same precious metal could be viewed alternatively as a good properly speaking, whose principal use is consumption, and as money, whose principal use is from now on exchange. Interestingly, Oresme hierarchized these two uses: employing metal for monetary purpose takes for granted that it is available in a quantity sufficient to guarantee that the satisfaction 
of its use as a good leaves a large enough surplus. Such a sequential mechanism was suggested when, for instance, Oresme claimed:

[T]here must be enough of such material. That is why, if there is not enough gold, money is also made of silver; but if one does not have these two metals or not in sufficient quantity, it is necessary to make an alloy or a simple money in another pure metal: thus it was formerly made of copper. ... [A] large quantity of these metals must not be allowed to be put to other use, to the extent that there is not enough left for money (Treatise on Money: ch. 2).

An important consequence of this sequential mechanism is that money cannot draw its value from its use in exchange, but that it is inherited from the secondary use, as a good, of the metal it is made of. Again in the Treatise, when discussing the genealogy of monetary transactions, Oresme argued: "[W]hen men first began to trade, or to compare wealth through the use of money, there was not yet any stamp or image on money; but a certain amount of silver or copper was given for a drink or food" (Treatise on Money: ch. 4).

Oresme's conception of money, whose value is determined by that of the metal as a commodity, and whose quantity depends on the importance of the transactions, should be regarded with circumspection. A classical interpretation of the first aspect, by Roscher (1862) to whom we are indebted for the rediscovery of Oresme's Treatise, and also taken up by Bridrey (1906), considered it as a prefiguration of the idea that the price of a good is determined by its rarity. However, discussions of the amount of silver "in proportion to natural wealth" (Treatise on Money: ch. 3), or of the relative values of gold and silver money (ibid.: ch. 10), show that the value of metal which is transferred to money is not related to its rarity but, in a quite common way, to its just price (see Gillard 1990; Lapidus 1997) - which explains the emphasis laid on the question of debasement of money, regarded as an injustice. Besides, the second aspect of Oresme's conception of money - the link between the quantity of money and the transactions it is used for - suggests some kind of prefiguration of a quantity theory of money (see, for instance, Arena 1987). However, here again, Oresme seems to have been more interested in structural adjustments between various kinds of money (gold, silver or black -that is, copper - money) which are imperfectly substitutable, and the corresponding types of commerce, than on simple quantitative relations between the overall stock of money and the overall volume of trade (Lapidus 1997: 32-4).

It is obvious that such a nuanced monetary analysis is worth considering directly through the contrast between a conventionalist and a metalist conception. It is also obvious that it is worth considering through its various policy implications, whether money does not constitute 
a limit to the power of the prince (Thomas Aquinas), or does constitute such a limit (Buridan and Oresme) - typically in the case of the debasement of money (see Lapidus 1997: 34-52). Nonetheless, where money was viewed as the possible object of a loan, the question of knowing whether its value is the consequence of a convention established by the prince or of the value of the metal it is made with, fades in favour of other issues concerning its ability to give birth to a specific income, and the possibility to separate its use from its ownership.

\section{Where does interest come from and why is it judged so badly?}

The Civil Law (Corpus Juris Civilis), built on the great texts of Roman law which were rediscovered during the first half of the eleventh century, provided an analytical framework which seems to have left no room for the possibility of interest. This was influential on Canon Law, especially for Gratian around 1140, who in his Decretum introduced the various decisions of the popes and of the Councils on usury, as well as for popes such as Gregory IX, Boniface VIII and Clement V, who completed the Corpus Juris Canonici. Moreover, the prohibition of usury reached its climax at the beginning of the fourteenth century, when Clement V promulgated a decretal at the Council of Vienna in 1311, according to which those who claimed that usury was not a sin should be punished as heretics. Numerous texts by theologians, including William of Auxerre, Robert of Courçon, Thomas Aquinas, Giles of Lessines, and Raymond of Peñaforte, supplemented this literature. All this shows the variety of the influences on the doctrine of usury: the Patristic literature came first, drawing on the teaching of the Scriptures. It was on this already well-established basis that both the Roman law and the rediscovery of Aristotle's moral and political philosophy gave the doctrine of usury the shape of the classical argument which Thomas Aquinas developed in the Summa Theologica $\left(\mathrm{II}^{\mathrm{a}}-\mathrm{II}^{\mathrm{ae}}\right.$, q. 78).

The decisive elements could be traced back to Christian antiquity, to the Greek and Latin Church Fathers who told, in various ways, the same instructive story: that of a consumption loan by a rich man who is widely provided for in all necessities, given to a poor man for whom obtaining the loan is a condition of survival (typical examples from the fourth century can be found in Gregory of Nazianzus or John Chrysostom). This story remained a reference point for centuries, and, later, most scholastic thinkers considered that in such a situation the "voluntary agreement" of both parties was not enough to prevent the loan from being usurious (see, for instance, Robert of Courçon at the beginning of the thirteenth century, for 
whom a poor man is not guilty of usury when he is obliged to borrow and pay interest ( $D e$ Usura: 17-19): this voluntary agreement was called "absolute" for the lender, but "conditioned" for the borrower.

This distinction, concerning the nature of an agreement, rests on a positive statement: the money loan can be understood as a particular case of voluntary exchange, after which neither the lender's nor the borrower's situation gets worse (and the lender's is clearly much better). This is a way to say that scholastic thinkers conceded that exchange is mutually advantageous. Of course, this was not specific to the analysis of a money loan: it clearly comes from the theory of the just price. Such was, for instance, Thomas Aquinas's position when, commenting on Aristotle's Politics, he wrote that "purchasing and selling were instituted for the common good of both parties, for each one needs the other's products and reciprocally" (Ethicorum, 1.V, lect.9, c; see also Summa Theologica, II ${ }^{\mathrm{a}}-\mathrm{II}^{\mathrm{ae}}$, q.77, a.1, resp.). This is a way to argue that some kind of surplus arises from a money loan as it does from every more standard type of voluntary exchange. Analytically, this also explains why interest is a withdrawal from this exchange surplus to the benefit of the lender. However, the story of the consumption loan has another consequence: it emphasizes the difference between the negotiating power of the lender and of the borrower. The lender is supposed to be vested with a much greater power than the borrower, so that he is able to appropriate most of the surplus emerging from exchange. We know that such a picture is highly disputable, at least in its practical relevance. The fourteenth century, for instance, presents several examples of loans where the borrower is the prince, so that the greater power of negotiation is on his side, the lenders being threatened with the loss of their capital - if not their lives. Nonetheless, the normative conclusion is straightforward: the condemnation of usury amounts to the condemnation of the appropriation of a part of the surplus arising from a loan.

Now, what is the proportion of the surplus above which a licit transaction, morally acceptable, would turn into a usurious transaction? Curiously, the primary impression produced by the literature on usury gives rise to two opposite answers. The story of the consumption loan is one where the total amount of the surplus falls into the hands of the lender: the loan has not helped the borrower escape misery. His situation after the loan is by no means better. The loan has just given him the opportunity to survive, as he did before. Usury might therefore be viewed as a situation in which the negotiating power of the lender is high enough to allow him to appropriate the whole surplus. By contrast, both the severity of the Church Fathers, and the popular knowledge based on the exempla to which Jacques Le 
Goff (1986) had devoted special attention, suggest that the slightest amount perceived above what is paid back would be usurious.

The contradiction is only apparent. The consumption loan story expresses constant suspicion of the lender, and the belief that his negotiation power usually gives him all that is possible under the condition of voluntary agreement by the borrower. The church shows such a strong aversion against this asymmetry of power that it finds it more appropriate to forbid any kind of supplement paid on a loan by the borrower.

The basis of such suspicion against the lender comes from the fact that usury as a sin is a sin of intention, which means that far from being self-evident from its factual existence, it depends on an intention, which is usually not observable to the moralist. In the early thirteenth century, for instance, William of Auxerre defined usury as "the intention to receive something more in a loan than the capital" (Summa Aurea, t.48, c.1, q.1). Though the formulation insists on the materiality of usury, a similar idea can be found in Robert of Courçon: "usury is a sin resulting from the fact of receiving or aiming at receiving something above the principal" (De Usura: 3 ; see also, ibid.: 13, 57, 61, and 78).

\section{Thomas Aquinas's classical argument}

Thomas Aquinas's argument against usury gave a rigorous basis to the prohibition of usury, in the sense of the payment of an income in reason of the loan itself. It might be considered as a development of three topics, coming from Roman law, from Canon law, and from the Aristotelian tradition, respectively. The first borrowed from the Digesta the contractual framework of the money loan; the second skilfully justified the choice of this framework by reversing the way the Decretum explains how an income is generated by a stock; the third draws on the Aristotelian analysis of the causes of exchange.

\section{The contractual framework of the money loan: the mutuum}

Even before Thomas Aquinas, the legal framework for money loans was a free contract for fungible goods, the mutuum (see Digesta, 44, 7, f.1, n.2, 4). When the underlying contract for a transaction is a mutuum, the nature of this contract itself precludes any interest being paid. Robert of Courçon, for example, at the very beginning of the thirteenth century, explained the mechanism by writing: 
[T] he name of the mutuum comes, indeed, from that which was mine [meum] becomes yours [tuum] or inversely. As soon as the five shillings that you lent me become mine, property passes from you to me. It would then be an injustice if, for a good which is mine, you were to receive something; for you are not entitled to any return from that which is my possession. (De Usura: 15)

In the mutuum, the prohibition of interest is linked to the fact that the money lent and the money paid back is not, physically, the same object, so that the ownership of the lender has to be interrupted at the beginning of the loan. Conversely, if they had been the same object, interest could have been charged on it because the lender would have kept his ownership throughout the duration of the loan while selling the use of it. This case was known as mutuum ad pompam. For Thomas Aquinas, the argument ran as follows: "silver money could have a secondary use: for instance, if money is conceded to somebody in order to make a display of it or to pawn it. And one can licitly sell such a use of money" (Summa Theologica, II $^{\mathrm{a}}-\mathrm{II}^{\mathrm{ae}}, \mathrm{q} .78$, a.1, ad 6).

Such a position was challenged throughout the Middle Ages, and even condemned by Pope Nicholas III in a decretal incorporated in Canon law (Decretales, Liber Sextus, V, tit.11, c.3, Exiit qui seminat), thus supporting non-Thomistic interpretations of usury. This clearly contradicts our current way of representing economic categories. We would accept that the money lent and the money paid back are not the same in the case of the mutuum, but because they are money at different dates, not because they are physically different objects. Thus, the case of the mutuum would be equivalent to that of the mutuum ad pompam. But we would also admit that the ownership of money is not interrupted by the loan since, apart from the time dimension, the money lent and the money paid back are perfect substitutes in both the mutuum and the mutuum ad pompam (Lapidus 1987, 1992). This disagreement is not easy to settle, because it is an ontological (and not an analytical) disagreement concerning the conception of economic categories. Nonetheless, the argument based on the mutuum is consistent, and leaves no room for a payment to the lender.

However, Roman law also acknowledged other contractual arrangements which would allow such a payment: the locatio, for instance, in which only the use of a thing is transferred from the lender to the borrower, its possession remaining unchanged; or the foenus, in which possession is transferred, but where such transfer is not free. This was far from entirely new at the time of Thomas Aquinas. But the effect of his contribution was to remove the possible arbitrariness of the choice of the mutuum as the contractual framework for money loans. 


\section{The nature of money}

This was made possible by reversing an argument concerning the reasons why a stock can be a source of income. This argument was presented in a well-known palea called Ejiciens, wrongly attributed to John Chrysostom, and integrated by Gratian in Canon law. The author of Ejiciens asked whether "the one who rents a field to receive its fruits or a house to receive an income is not similar to the one who lends money at usury" (Decretum, dist.88, can.11). The negative answer favoured three reasons:

First, because the only function of money is the payment of a purchase price. Then, because the farmer makes the earth fructify, the tenant takes advantage of inhabiting the house: in both cases, the owner seems to give use of his thing to receive money and, in a certain way, he exchanges gain for gain, whilst from money which is stored up, you make no use. At last, its use gradually exhausts the earth, deteriorates the house, whilst the money lent suffers neither diminishing nor ageing. (ibid.)

The first reason recalls the Aristotelian argument about the sterility of money. The second argues that the income should arise from a pre-existing surplus, like that which comes from production. The third reason is decisive: it asserts that a stock is a source of income from the moment the stock begins to depreciate. This income is then defined as the counterpart of this depreciation. Now, the great skilfulness of Thomas Aquinas was to reverse Ejiciens' third reason (see Noonan 1957: 54-5). His argument was expounded in De Malo (q.13, a.4c) or in the Summa Theologica:

\footnotetext{
One must know that the use of certain things is identical with their consumption ... In such [exchanges], one must not count the use of the thing apart from the thing itself but, as a result of conceding the use, the thing itself is conceded. And this is why, for such things, the loan transfers property. Thus, if someone wanted to sell wine on the one hand and the use of wine on the other hand, he would sell twice the same thing or sell what is not ... Conversely, there are things the use of which is not their consumption. So, the use of a house is to live in, not to destroy it. Therefore, one can concede separately use and property. (Summa Theologica, $\mathrm{II}^{\mathrm{a}-} \mathrm{II}^{\mathrm{ae}}$, q.78, a.1, resp.)
}

As a result, interest as an income no longer proceeded from the depreciation of a stock but from the possibility of separating property and use - the sale of the latter producing the income. Therefore, a house or a field could - as in Ejiciens, but for another reason - be the source of an income, while bread, wine and, of course, money could not.

\section{The material and the formal causes of exchange}

Far from being a consequence of a possibly arbitrary decision of a moralist or a lawyer, the choice of the mutuum for a money loan now came from the nature of the object of the 
transaction: this means that the nature of money itself, as a thing whose possession cannot be separated from its use, determined the nature of the contract. This conception of money was explained by Thomas Aquinas chiefly in his commentaries on Aristotle, from whom he claimed he had borrowed it.

It was when commenting on Aristotle's Politics that Thomas Aquinas stressed the conventional nature of money (Politicorum, I, 7). For Thomas, this meant that it was a product of human reason, as the most complete form of exchange. In this respect, he pointed out two functions of money, which he discussed at length when commenting on Peter Lombard's Sentences, on the Politics or on the Ethics and, of course, in the Summa. The first function of money stood in the Aristotelian tradition - it is a medium of exchange: "But money, according to the Philosopher [Aristotle] in the Ethics (V, 5) and in the Politics (I, 3), was principally invented to facilitate exchanges: and so, the proper and principal use of money is to be consumed without diversion, because it is spent in exchanges" (Summa Theologica, $\mathrm{II}^{\mathrm{a}-}-\mathrm{II}^{\mathrm{ae}}$, q.78, a.1, resp.). In this regard, usurious activity is considered as distorting the nature of money (Politicorum, I, 8).

Thomas Aquinas was not so faithful to Aristotle when introducing the second function of money - the unit of account:

All other things have from themselves some utility: however, this is not the same for money. But it is the measure of the utility of other things, as it is clear from the Philosopher in the Ethics (V, 9). And therefore the use of money does not hold the measure of its utility from this money itself but from the things which are measured by money according to the various people who exchange money for goods. Hence, receiving more money for less seems nothing else than differentiating the measure in giving and receiving, which obviously brings inequity. (In IV Libros Sententiarum, 1.III, dist.37, a.1, q.16)

This contrasts with Aristotle's original position, according to which "money itself is submitted to depreciations, for it has not always the same purchasing power" (Ethics, V, 5:14). However, this emphasis on money as a unit of account, therefore free from either appreciations or depreciations, meant that it could not give rise to any supplementary income.

In spite of their discrepancies, the various sources of Scholastic thought continued along the same lines as Thomas Aquinas's construction: the nature of money and the contractual framework thereby induced rendered impossible the charging of interest on a money loan. This impossibility is, first of all, a positive one: interest, as generated by the money loan itself, can simply not exist. So that, if interest happens to be associated with a money loan, its amount must be explained on another basis than the money loan itself. 


\section{Interest without usury}

The literature on usury shows that the range of analytically acceptable explanations of the existence of interest was limited. Each attempt to give an alternative explanation therefore reveals to the moralist that the income perceived by the lender was only due to his negotiation advantage, and had to be viewed as usurious.

The starting point was the widespread idea that for both the lender and the borrower, a present and a future good are not worth the same. "One harms one's neighbour", wrote Thomas Aquinas, "when preventing him from collecting what he legitimately hoped to possess. And then, the compensation should not be founded on equality because a future possession is not worth a present possession" (Summa Theologica, $\mathrm{II}^{\mathrm{a}}-\mathrm{II}^{\mathrm{ae}}$, q. 62, a. 4, resp. 2; see also his disciple, Giles of Lessines, De Usuris, c.9). This was a way to say that although the legitimacy of interest paid on a loan does not depend on the loan itself, it might depend on the harm generated by the loan. Also, when interest compensates the harm suffered by the lender, the operation is not usurious. Extrinsic titles aim, precisely, at identifying this harm.

The same intertemporal framework of the loan contract opens the path to another issue. It is obvious - both for us today, as it was as for medieval merchants, lawyers or theologians that several intertemporal operations (credit sale or census, for example) stand as close substitutes for an interest loan. Disregarding the possibility of a compensation for the harm suffered by the lender, this would mean that the strict prohibition of usury might be bypassed through a close substitute for an interest loan. Noticeable efforts were devoted to the attempt to identify the conditions under which an intertemporal operation, giving rise to interest, counts as (or doesn't count as) a usurious transaction.

Anyway, in both cases (the compensation of harm, or an intertemporal operation generating an income), the practical difficulty is the same: how can we be sure that the income gained by one of the partners of the transaction does not result from his superior power in the negotiation?

\section{Extrinsic titles}

Exterior to the loan contract and providing reasons for a compensating payment, the so-called "extrinsic titles" might be viewed as attempts to account for the harm suffered by the lender, according to its nature. These extrinsic titles, such as poena conventionalis, damnum 
emergens or lucrum cessans, existed separately from the mutuum, and gave, for each of them, reasons for the payment received by the lender. A general problem linked to extrinsic titles is that although some of them became widely accepted, the harm often remained unobservable, so that the possibility of a usurious transaction could not be totally avoided. The level of acceptation or refusal of the extrinsic title therefore depended less on the nature of the alleged harm than on the trust or distrust on the effectiveness of this harm.

Designed to protect the creditor from a possible failure of the debtor to repay the loan in time, the poena conventionalis stipulated a daily indemnity in case the expiry date was not respected. Through the damnum emergens, the prejudice to the lender was described as his sacrifice, in terms of consumption, in order to keep his money available for lending. The lucrum cessans widened the perspective to the profitable operations which would have to be given up in order to carry out the loan, so that the prejudice was the sacrifice of a possibility of profit.

The damnum emergens and the lucrum cessans make obvious the working of the harmcompensation mechanism. As Noonan (1957: 116) pointed out, these two titles were not really discussed before the mid-thirteenth century (with the exception of Robert of Courçon, who condemned the lucrum cessans; De Usura: 61-3) since they needed, as a prerequisite, a general agreement about the use of the mutuum for a money loan. Thomas Aquinas, despite showing a certain mistrust - chiefly aimed at the lucrum cessans - clearly stated the principles on which they were founded:

\footnotetext{
In his contract with the borrower, the lender may, without any sin, stipulate an indemnity to be paid for the prejudice he suffers while being deprived of what was his possession; this is not to sell the use of money, but to receive a compensation. Besides, the loan may spare the borrower a greater loss than the one to which the lender is exposed. It is thus with his benefit that the first makes up the loss of the second. (Summa Theologica, $\mathrm{II}^{\mathrm{a}}-\mathrm{II}^{\mathrm{ae}}$, q.78, a.2, ad. 1)
}

In spite of an earlier and more general acceptance, the poena conventionalis also illustrates the possibilities for manipulation that the extrinsic titles afforded the lender. This could be done in two different ways. First, the duration of the loan might have been so short that the borrower could by no means pay back in time. Naturally, this practice was clearly condemned, but the fault was not that easy to establish. Second, the lender could increase the indemnity mentioned at the beginning of the contract so that it was higher than the loss he suffered because of the non-availability of his money at the expiry date. Some scholastic authors expressed this last argument quite systematically, such as Raymond of Peñaforte who 
claimed that "if the penalty proceeds from a convention, that is from a common agreement between the parties mentioned in the contract, so that at least the fear of this penalty forced payment at the expiry date, there is no usury" (Summa de Casibus Conscientiae, II, par.5; see also Robert of Courçon, De Usura: 65-7). John Duns Scotus, some 60 years later, was even more precise when writing: "An obvious sign that a penalty is not usurious is the following: the merchant prefers to have his money back at the expiry date rather than the day after, accompanied by a penalty" (In Quattuor Libros Sententiarum, Opus oxoniensis, IV, dist.15, q.2, 18).

The principle of an interest that was both analytically and morally acceptable therefore appeared as an outcome of the discussions on the mutuum and the major extrinsic titles. The emphasis laid on the fact that the interest was a compensation for the specific harm suffered by the lender, and not a product of the loan itself, shows that it might be understood as the opportunity cost of the loan. This opportunity cost is the key to the distribution of the surplus of exchange between the lender and the borrower: after the payment of an interest equal to the cost of opportunity of the loan, the respective situations of the lender and of the borrower have improved.

Naturally, this requires the credibility, for the moralist, of the harm alleged by the lender. In case the fear of a mortal sin was not sufficient to move the latter away from a usurious transaction, this might constitute an evident weakness of the system. This explains the importance granted, in the discussions between schoolmen, to the nature of the harm associated with each extrinsic title. For instance, it justifies the quite general mistrust about the lucrum cessans (when compared to the damnum emergens): not because this kind of prejudice was inexistent, but because it concerns, by nature, professional merchants who are always suspected of taking advantage of their superior power of negotiation. This also explains the poor confidence, even during the sixteenth century, in a loan where the interest paid is supposed to compensate an insufficiently specified harm: the late extrinsic title called carentia pecuniae.

\section{Substitutes for an interest loan}

Whereas the extrinsic titles added something more to the main loan contract, a complementary possibility for a potential lender to draw an income was to replace the interest money loan by another intertemporal operation for which it was a close substitute. 
The difficulty of the problem faced by the moralists came from the ability of the merchants to construct such close substitutes: credit sale, anticipated payment, census, societas, triple contract, mohatra, mortgage, foenus nauticum, bank deposit, etc. The case of the census, which appeared in the thirteenth century, is significant. Initially, it had nothing to do with a loan since it consisted in the sale of a productive good - land, for instance, or cattle - bought with the products of its exploitation. As such, this is a sale, and apparently the only disputed question concerns knowing how many times the annual product had to be paid for a census. However, if the seller of the census had already bought it for cash from his buyer, he clearly becomes the equivalent of a lender receiving interest. As a simple sale, the census would be licit, as Giles of Lessines (De Usuris, c.9) acknowledged. But alternatively, it could also be the basis of a usurious loan, as Robert of Courçon explained (De Usura: 63).

The solution for separating usurious from legitimate transactions in the presence of these kinds of substitutes was to find among them a characteristic which allowed such a separation. Property could be viewed as such a characteristic: in the mutuum, the interruption in property made impossible the receipt of an income by the lender; continuous property might, on the contrary, support a claim for such income. However, the institutional arrangements of the transaction can conceal the reality of the ownership. The societas illustrates this point. In Roman law, this is an association between persons who engaged their labour, money or goods in a profitable operation. The income of each member of the societas depends, naturally, on the issue of the operation. Every modality of sharing was allowed. However, in the Middle Ages, this excluded the modality in which one partner would bear the entire responsibility in case of loss. Robert of Courçon expressed this by writing that "every merchant contracting with another for trading must, if he wishes in participate to profit, show that he participates in the danger and expenses which attend all buying and selling" (De Usura: 73).

This shows that, in turn, the claim for property was not enough to ensure its reality, and that beyond its formal existence, a supplementary characteristic of this property was required in order to consider it as able to produce non-usurious income for the owner. Robert of Courçon's reference to the participation "in the dangers" accounts for the commonly held idea that risk-taking was this supplementary characteristic. Furthermore, the general principle was stated by Thomas Aquinas as follows:

The one committing his money to a merchant or a craftsman by means of some kind of partnership does not transfer the property of his money to him, but it remains his possession; so that at his [the lender's] 
risk, the merchant trades or the craftsman works with it; and he can thus licitly seek a part of the profit as coming from his own property. (Summa Theologica, IIa-IIae, q.78, a.2, obj.5)

A significant expression of the role granted to risk for assessing the legitimacy of a transaction was the well-known decretal Naviganti by Pope Gregory IX:

Somebody lending a certain quantity of money to one sailing or going to a fair in order to receive something beyond the capital, for he takes the risk upon himself, is to be thought a usurer. Also the one who gives ten shillings to receive after a certain time the same measure of grain, wine or oil, though it is then worth more, when one really doubts whether it will be worth more or less at the date of delivery, must not, for that, be considered a usurer. Because of this doubt again, the one who sells bread, grain, wine, oil or other commodities so that he receives after a certain period of time more than they are worth then, is excused if, in lack of a forward contract, they would not have been sold. (Decretales, 15, tit. 19, c. 19, Naviganti)

This decretal is highly questionable (see Mc Laughlin 1939: 103-4 or Noonan 1957: $137 \mathrm{ff}$.). At first glance, it seems to adopt successively two opposite positions concerning the effects of risk: the first sentence condemns the sea loan (foenus nauticum) while the concluding sentences allow a reduction in price in the case of anticipated payment - and an increase in the case of a credit sale - if the future value of the sold commodity is uncertain. The difference in treatment is large enough to have led some commentators to imagine that the condemnation of the foenus nauticum could have proceeded from an error of transcription by the Pope's secretary, Raymond of Peñaforte.

However, a careful examination suggests more consistent interpretations. The first rests on the expression "is to be thought a usurer" (usurarius est censendus). Usury being a sin of intention, this means that, in the foenus nauticum, receiving an income is not in itself usurious, but an external observer will be far from certain that the lender is not overestimating the risk of the operation to disguise a usurious benefit as a legitimate income.

Such a "moral hazard" interpretation of Naviganti was suggested by Goffredus of Trani (see McLaughlin 1939: 103, or Noonan 1957: 139). Besides this, it may also be noticed that the foenus nauticum is not such a simple operation, where only two states of the world can occur - the freight arrives safe and sound or perishes at sea. Actually, if the freight is intact, the merchant will run another risk when selling it. This last risk is not taken into account in the contract between the lender and his borrower. So that, in the event of the ship not sinking, one party has to assume the entire responsibility if a loss occurs. As the possibility of selling overseas is submitted to the advance of capital which belongs to the lender for the duration of the crossing, there is no reason for this ownership to be transferred to the borrower during the 
second phase of the operation. In spite of its name, the foenus nauticum is clearly not a loan, but rather similar to a kind of partnership (a societas) which allows common ownership of money invested in a presumably profitable operation. This strictly forbids any partner from escaping, at any moment, from the risk of loss.

This shows the utmost importance of risk-bearing as sign of a lender's continuous property during an intertemporal operation, therefore allowing the payment of a non-usurious income (see, for instance, the cases of venditio sub dubio, where a real doubt concerns a credit sale or an anticipated payment). Nonetheless, this did not nullify the suspicion concerning the lender's intention, despite the imaginative conditions imposed by some theologians (see, for example, Giles of Lessines for whom the same doubt should exist for both the lender and the borrower, De Usuris, c.9), or the typical medieval solution of the resort to an expert, a wise man, already advocated by William of Auxerre in the Summa Aurea (De Usura, c.3, q.2).

\section{Concluding Remarks}

In the two questions from Thomas Aquinas's Summa Theologica respectively devoted to them, both price and the interest loan were taken up as special applications of a theory of justice. An outstanding and obvious consequence is that understanding these two economic categories rests on the coexistence of a norm which satisfied the requirements of justice, and of a departure from this norm which explains actual behaviour, usually from a moral point of view. Their respective futures were nevertheless quite different.

The construction of a theory of price drawing on a comparative approach between hierarchized concepts of valuation clearly survived the initial concerns expressed by theologians and lawyers from the Middle Ages. Their legacy can be followed (see Lapidus 1986), from the revival of Thomism within the School of Salamanca during the sixteenth century, to the foundation of what was later called "modern" theories of natural law in the works of Grotius and Pufendorf, one century later, and, at last, to the dissemination of their ideas in Great Britain, at the very origin of the School of Glasgow, by Gershon Carmichael and Francis Hutcheson - Adam Smith's most admired predecessor. So when Smith explained to his students (Lectures on Jurisprudence, LJB: 494; see also LJA: 353), that "[o]f every commodity there are two different prices, which tho' apparently independent will be found to 
have a necessary connection, viz. the natural price and the market price", he made use of the same comparative approach as his predecessors did, but now free from its submission to moral ends. Though the market price is interpreted, in the Lectures and, later, in the Wealth of Nations, in relation to the natural price, as the current price was interpreted in relation to the just price, the possible differences are no longer considered in terms of the morality of the partners to the transaction. Economic matters had become worthy of being studied in themselves. However, the way price was understood by most classical economists, from Smith to Marx, retained the hallmark of the intellectual device originated by schoolmen, several centuries earlier.

The difficulties facing the understanding of interest at the turn of the thirteenth century were different. From Augustine, for instance, the authors of this period already knew what was later forgotten by Bernard of Mandeville: that trade is not, by nature, dishonest. However, the proliferation of substitutes for money interest loans and of the institutional possibilities for a lender to manipulate the information about the harm he suffers as a result of a loan, increased both the suspicion of trade in general, and the obsolescence of the various mechanisms used to avoid usury loans: the reinforcement of the prohibition of usury came along with a lessening of its efficiency.

The reason for this dead end was the lack of information, on the part of the theologians or the lawyers, concerning the precise conditions under which such a loan would be nonusurious. Whereas for price the problem concerned the moral assessment of a possible departure from the norm of the just price, this very norm was only imperfectly known in the case of a money loan. The intellectual conditions for a renewal of economic ideas about interest therefore came from a transformation of the norm and of its role, making its identification easier, and progressively superfluous.

The first actual deviation from the Thomistic representation was a consequence of the growing awareness of the unexpected effects of a strict attitude toward interest loans - an attitude which prohibited most of them on the basis of the slightest suspicion of a usurious intention. John of Gerson, Chancellor of the University of Paris, noticed in the 1420s that such an attitude might result in increased poverty and crime. From a moral point of view, this amounted to the provocative claim that in some cases, a good might result in an evil. Gerson's provocative solution was that a good might arise from a moderate evil. In other words, that light usuries help the indigent and prevent him from sliding into crime. Obviously, this did not completely dismiss the Thomistic representation of the money loan: it 
only led to considering that the lender's appropriation of the exchange surplus above the nonusurious part might constitute a referential norm, evidently more distant from an evangelical ideal, but more in accordance with usual economic practices.

Much later, at the beginning of the seventeenth century, the Jesuit Leonard Lessius proposed the introduction of a new extrinsic title, named carentia pecuniae, according to which the harm suffered by the lender would depend not on what he was prevented from doing with his money but, more generally, on the fact that this money was missing (see Van Houdt 1998). The carentia pecuniae had a far-from-favourable reception: suspicion of potential lenders was too high to exempt them from giving detailed information about the harm associated with a loan. However, this was also a way to increase the gap with the classical argument on usury: it could be admitted that a money loan did not bring any income to the lender by reason of the loan itself, but only because of the harm that it generated. Now, what remains of the classical argument when the nature of the harm was only that the money lent was missing? One step more, and the same analyses could be extended to the case where money is desirable in itself and where the rate of interest is its price. Through their diversity, the mercantilist and classical analyses showed that the giving up of the moral imperatives inherited from the Middle Ages allowed a re-composition of the medieval ingredients of the theory of interest. John of Gerson and Leonard Lessius had paved the way. The resulting theoretical elaborations were, of course, different, but the constitutive elements needed no substantial change.

See also:

Economics and philosophy; Money and banking; Value and price.

\section{References and further reading}

Arena, R. (1987), 'Réflexions sur la Théorie Monétaire de Nicole Oresme', in Actes du Colloque Oresme, Paris: Belles Lettres and Beltrame: Uno piu Uno.

Aristotle (1934), Ethics, London: J.M. Dent and New York: E.P. Dutton.

Aristotle (1981), Politics, Harmondsworth: Penguin.

Baldwin, J.W. (1959), 'The medieval theories of the just price' (monograph), Transactions of the American Philosophical Society, 49 (4). 
Barath, D. (1960), 'The just price and costs of production according to Thomas Aquinas', New Scholasticism, 34 (4), 413-30.

Bridrey, E. (1906), La Théorie de la Monnaie au XIVe siècle - Nicole Oresme, Paris: Giard et Brière, reprinted 1978, Geneva: Slatkine.

Buridan, J. (1637), Quaestiones in Decem Libros Ethicorum Aristotelis ad Nichomachum, Oxford: H. Cripps.

Buridan, J. (1640), Quaestiones in Octo Libros Politicorum Aristotelis, Oxford, G. Turner.

De Roover, R. (1958), 'The concept of the just price: theory and economic policy', Journal of Economic History, 18 (4), 418-34.

De Roover, R. (1971), La Pensée Economique des Scolastiques, Montreal and Paris: Vrin.

Decretum, in Corpus Juris Canonici (1879-81), 2 vols, vol. 1, Leipzig: B. Tauchnitz.

Digesta, in Corpus Juris Civilis, vol. 1, reprinted 1968, Dublin and Zurich, Weidmann.

Ege, R. (2014), 'La question de l'interdiction de l'intérêt dans l'histoire européenne: un essai d'analyse institutionnelle', Revue Economique, 65 (2), 391-417.

Fau, J. (ed.) (1990), Nicolas Oresme [1355], Traité Monétaire - Treatise on Money, Paris: Cujas.

Friedman, D.D. (1980), 'In defense of Thomas Aquinas and the just price', History of Political Economy, 12 (2), 234-42.

Giles of Lessines (1871-80), De Usuris, in T. Aquinas, Opera Omnia, eds P. Mare and S.E. Frette, vol. 28, Paris: Vivès.

Gillard, L. (1990), 'Nicole Oresme, Economiste', Revue Historique, 279 (1), 3-39.

Gilson, E. (1944), History of Christian Philosophy in the Middle Ages, reprinted 1955, London: Sheed \& Ward.

Gordon, B. (1961), 'Aristotle, Schumpeter, and the metalist tradition', Quarterly Journal of Economics, 75 (4), 608-14.

Grice-Hutchinson, M. (1952), The School of Salamanca - Readings in Spanish Monetary Economy, 1544-1605, Oxford: Clarendon Press.

Grice-Hutchinson, M. (1978), Early Economic Thought in Spain: 1177-1740, London: George Allen \& Unwin. 
Henry of Langenstein (Henry of Hesse) (s.d.), Tractatus de Contractibus et Origine Censuum, in John of Gerson (1484), Opera Omnia, vol. 4, Cologne: Johannes Koelhoff, pp. $185-224$.

Hollander, S. (1965), 'On the interpretation of the just price', Kyklos, 18 (4), 615-34.

Scotus, J.D. (1891-95), In Quattuor Libros Sententiarum, op. oxoniensis, in Opera Omnia, vol. 18, reprint of L. Wadding (ed.) 1639 edn, Paris: Vivès.

John of Gerson (1483-84), Opera Omnia, 4 vols, Cologne: Johann Koelhoff.

Johnson, C. (1956), The 'De Moneta' of Nicholas Oresme, London: Nelson.

Keynes, J.M. (1936), General Theory of Unemployment, Interest and Money, in E. Johnson and D. Moggridge (eds) (1973), The Collected Writings of John Maynard Keynes, vol. 7, London: Royal Economic Society.

Langholm, O. (1983), Wealth and Money in the Aristotelian Tradition, Bergen, Oslo, Stavanger and Tromsø: Universitetsforlaget.

Langholm, O. (1984), The Aristotelian Analysis of Usury, Bergen and Oslo: Universitetsforlaget.

Langholm, O. (1987), 'Scholastics Economics', in S.T. Lowry (ed.), Pre-Classical Economic Thought, Boston, Dordrecht and Lancaster: Kluwer Academic, pp. 115-35.

Langholm, O. (1992), Economics in the Medieval Schools, Leiden, New York and Cologne: E.J. Brill.

Lapidus, A. (1986), Le Détour de Valeur, Paris: Economica.

Lapidus, A. (1987), 'La Propriété de la Monnaie: Doctrine de l'Usure et Théorie de l'Intérêt', Revue Economique, 38 (6), 1095-110.

Lapidus, A. (1991), 'Information and risk in the medieval doctrine of usury during the thirteenth century', in W. Barber (ed.), Perspectives in the History of Economic Thought, vol. 5, Aldershot, UK and Brookfield, VT, USA: Edward Elgar, pp. 23-38.

Lapidus, A. (1992), 'Introduction à la Pensée Economique Médiévale,' in A. Béraud and G. Faccarello (eds), Nouvelle Histoire de la Pensée Economique, vol. 1, Des scolastiques aux classiques, Paris: La Découverte, pp. 24-70. 
Lapidus, A. (1994), 'Norm, virtue and information: the just price and individual behaviour in Thomas Aquinas' Summa Theologiae', European Journal of the History of Economic Thought, 1 (3), 435-73.

Lapidus, A. (1997), 'Metal, money, and the prince: John Buridan and Nicholas Oresme after Thomas Aquinas', History of Political Economy, 29 (1), 21-53.

Le Bras, G. (1950), 'La Doctrine Ecclésiastique de l'Usure à l'Epoque Classique (XIIèmeXIVème siècles)', in A. Vacant, E. Mangenot and E. Amann (ed.), Dictionnaire de Théologie Catholique, vol. 15 (2), Paris: Letouzey et Ané, col. 2336-72.

Le Goff, J. (1986). Your Money or Your Life: Economy and Religion in the Middle Ages, New York: Zone Books.

Lombard, A. (Alexander of Alexandria) (1962), Tractatus de Usuris, in A.-M. Hamelin (ed.), Un Traité de Morale Economique au XIVe Siècle, Leuven: Nauwelaerts, Montreal: Librairie Franciscaine and Lille: Giard.

McLaughlin, T.P. (1939), 'The teaching of the canonists on usury (XIIth, XIIIth and XIVth centuries)', pt 1, Mediaeval Studies, 1, 81-147.

Noonan, J.T. Jr (1957), The Scholastic Analysis of Usury, Cambridge, MA: Harvard University Press.

Oresme, N., Traduction et Glose de la Politique d'Aristote, in A.D. Menut (1970), Maître Nicole Oresme: Le Livre des Politiques d'Aristote, Transactions of the American Philosophical Society, 60 (6), 1-392.

Oresme, N., Traduction et Glose de l'Ethique à Nicomaque d'Aristote, in A.D. Menut (1940), Maître Nicole Oresme: Le Livre de Ethique d'Aristote, New York: Stechert.

Oresme, N., Treatise on Money, in J. Fau (1990), Nicolas Oresme [1355], Traité Monétaire - Treatise on Money, Paris: Cujas, Latin-French-English edn based on a Latin version constituted from five Latin manuscripts, published in C. Johnson (1956), the original French version being published as Traictie de la Première Invention des Monnoies, by L. Wolowski (ed.) (1864).

Raymond of Peñaforte (1744), Summa de Casibus Conscientiae, Verona. 
Robert of Courçon (1902), De Usura, in G. Lefevre (ed), Le Traité 'De Usura' de Robert de Courçon, Travaux et Mémoires de l'Université de Lille, vol. 10, m. 30, Lille: University of Lille.

Roscher, W. (1862), 'Un Grand Economiste Français du XIVème Siècle', Compte-Rendus de l'Académie des Sciences Morales et Politiques, reprinted in L. Wolowski (ed.) (1864), Traictie de la Première Invention des Monnoies de Nicole Oresme et Traité de la Monnoie de Copernic, Paris: Guillaumin, reprinted 1969, Rome: Bizzarri.

Schumpeter, J.A. (1954), History of Economic Analysis, London: Allen \& Unwin.

Smith, A. (1762-63), Lectures on Jurisprudence (LJA), reprinted 1978, Oxford: Clarendon Press.

Smith, A. (1766), Lectures on Jurisprudence (LJB), reprinted 1978, Oxford: Clarendon Press.

Sommerville, H. (1931), 'Interest and usury in a new light', Economic Journal, 41 (December), 646-9.

Thomas Aquinas (1871-80), Opera Omnia, eds P. Mare and S.E. Frette, Paris: Vivès.

Thomas Aquinas, De Malo, in Opera Omnia, eds P. Mare and S.E. Frette (1871-80), Paris: Vivès, vol. 13.

Thomas Aquinas, In IV Libros Sententiarum, in Opera Omnia, eds P. Mare and S.E. Frette, vol. 10, Paris: Vivè.

Thomas Aquinas, In VIII Libros Politicorum, in Opera Omnia, eds P. Mare and S.E. Frette, vol. 26, Paris: Vivè.

Thomas Aquinas, In X Libros Ethicorum ad Nichomachum, in Opera Omnia, eds P. Mare and S.E. Frette, vol. 25, Paris: Vivè.

Thomas Aquinas, Summa Theologica, in Opera Omnia, eds P. Mare and S.E. Frette, vol. 3, Paris: Vivè.

Tortajada, R. (1992), 'La Renaissance de la Scolastique, la Réforme et les Théories du Droit Naturel', in A. Béraud and G. Faccarello (eds), Nouvelle Histoire de la Pensée Economique, vol. 1, Paris: La Découverte, pp. 71-91. 
Van Houdt, T. (1998), “Lack of money": a reappraisal of Lessius' contribution to the scholastic analysis of money-lending and interest-taking', European Journal of the History of Economic Thought, 5 (1), 1-35

William of Auxerre (1986), Summa Aurea, Paris: CNRS.

Wilson, G.W. (1975), 'The economics of the just price', History of Political Economy, 7 (1), $56-74$.

Wolowski, L. (ed.) (1864), Traictie de la Première Invention des Monnoies de Nicole Oresme et Traité de la Monnoie de Copernic, Paris: Guillaumin, reprinted 1969, Rome: Bizzarri.

Worland, S.G. (1977), 'Justum pretium: one more round in an endless series', History of Political Economy, 9 (4), 504-21. 